\title{
OPTIMALISASI FUNGSI PIGMEN BUNGA MAWAR SORTIRAN SEBAGAI ZAT PEWARNA ALAMI DAN BIOAKTIF PADA BEBERAPA PRODUK INDUSTRI
}

\author{
ELFI ANIS SAATI, ${ }^{1}$ THEOVILLA RRD., ${ }^{2}$ SIMON BW., ${ }^{3}$ DAN AULANNI'AM ${ }^{4}$ \\ ${ }^{1}$ Staf Pengajar Jurusan Ilmu \& Teknologi Pangan FPP-Univeritas Muhammadiyah Malang \\ ${ }^{2}$ Alumni Jurusan Ilmu \& Teknologi Pangan Univeritas Muhammadiyah Malang \\ ${ }^{3}$ Guru Besar Jurusan THP FTP-Universitas Brawijaya Malang \\ ${ }^{4}$ Guru Besar Fakultas Kedokteran Hewan-Universitas Brawijaya Malang \\ E-mail: elfiumm@yahoo.co.id
}

\begin{abstract}
ABSTRAK
Mawar diketahui mengandung pigmen antosianin dan sebagai senyawa bioaktif yang dapat bertindak sebagai bahan penangkap radikal bebas. Ketika musim panen tiba jumlahnya akan sangat berlimpah. Bunga sortiran yang dapat menurunkan harga jual dapat diolah dalam bentuk pewarna alami untuk makanan, kosmetik dan obat/herbal. Tujuan penelitian ini adalah untuk mengetahui kualitas ekstrak mawar pasca-potong bunga, dan mengetahui pengaruh aplikasi produk pigmen antosianin naik menjadi kualitas beberapa percobaan produk. Penelitian dilakukan dalam dua tahap. Tahap I menguji kualitas ekstrak pigmen pasca-potong bunga mawar dalam 3 tingkat (segar, 2 dan 4 hari), yang dilakukan dengan menggunakan rancangan acak kelompok. Tahap II adalah penerapan produk pigmen bunga mawar merah pada beberapa produk industri (produk makanan yaitu, herbal dan kosmetik), menggunakan desain sesuai dengan target masing-masing. Hasil penelitian menunjukkan bahwa pigmen antosianin naik 3,5\% efektif menyumbangkan merah dan kuning pada beberapa produk industri seperti jus buah, yoghurt, selai, minuman berkarbonasi (makanan) dan body lotion (kosmetik), dan dapat berkontribusi pada warna alami pada suatu waktu yang berfungsi sebagai sumber bioaktif dalam tablet effervescent.
\end{abstract}

Kata kunci: anthocyanin pigment, mawar, bioactive, produk industri

\begin{abstract}
The roses known as containing anthocyanins pigments and acting as bioactive compound which become free radical catcher material. When harvest season arrives, the number will be very abundant. Sorting flowers which can decrease the selling price can be processed in the form of natural dyes for food, cosmetics and medicines/herbs. The purpose of this study is identifying quality extract of post-cut roses flowers, and the effect of anthocyanin pigment product applications to the quality of some industrial products.The experiment was conducted in two stages. Phase I is testing the quality of the pigment extracts of post-cut roses flowers in 3 levels (fresh, 2 and 4 days), that performed using randomized block design. Phase II is the application of pigment products of red roses on some industrial products (ie food products, herbal and cosmetics), using the design in accordance with their respective target. The results showed that the anthocyanin pigment rose $3.5 \%$ effective donate red and yellow on some industrial products such as fruit juice, yoghurt, jelly, carbonated beverage (food) and body lotion (cosmetic), and can contribute to the natural color at a time serves as a source of bioactive in effervescent tablets.
\end{abstract}

Key words: anthocyanin pigment, rose, bioactive, industrial product

\section{PENDAHULUAN}

Warna yang tampak pada makanan dikarenakan dua hal, yaitu penambahan pewarna sintetis dan karena adanya pigmen alami atau tanpa tambahan bahan dari luar. Dalam Undang-undang Pangan RI Nomor 7 Tahun 1996, keamanan pangan didefinisikan sebagai kondisi dan upaya yang diperlukan untuk mencegah pangan dari kemungkinan cemaran biologis, kimia dan benda lain yang dapat mengganggu, merugikan dan membahayakan kesehatan manusia. Keamanan pangan ini berkaitan erat dengan sanitasi pangan, bahan tambahan makanan, rekayasa genetika dan radiasi pangan, kemasan pangan, jaminan mutu pangan dan pemeriksaaan laboratorium serta pangan tercemar (Depkes RI, 2000). Padahal kenyataan di Indonesia, dalam melakukan bisnisnya produsen makanan masih banyak menggunakan bahan tambahan makanan (food additive) yang kurang terpantau baik dalam ketepatan bahan yang digunakan maupun dosis yang digunakan, diantaranya adalah zat pewarna seperti laporan 
hasil survey BPOM bahwa beberapa produk industri seperti makanan-minuman dan kosmetik amat membutuhkan sumbangan warna merah, oranye dan merah-keunguan dari pewarna sintetis bahkan pewarna yang berbahaya seperti Rhodamin $B$, Methanil yellow dan Amaranth serta merah K3, K10 (Kompas, 2009).

Pigmen antosianin adalah pigmen yang bersifat larut air, terdapat dalam bentuk aglikon sebagai antosianidin dan glikon sebagai gula yang diikat secara glikosidik. Bersifat stabil pada $\mathrm{pH}$ asam, yaitu sekitar 1-4, dan menampakkan warna oranye, merah muda, merah, ungu hingga biru (Li, 2009; Lewis et al., 1997). Mawar (Rosa sp.) merupakan salah satu bunga potong yang banyak diminati masyarakat, yang seringkali digunakan sebagai bunga penghias acara formal seperti seminar, lokakarya maupun non formal seperti pengantin dan beberapa acara adat. Jika acara-acara telah usai atau bunga mawar disimpan/dipajang beberapa hari akan menjadi layu dan jatuh harga jualnya. Padahal bunga mawar sortiran (tidak segar lagi) tersebut, ternyata masih mengandung pigmen antosianin berjenis Malvidin dan Sianidin glikosida (Saati, 2011) dan berkhasiat sebagai obat alami (Rukmana, 1995). Dibalik keelokan warna bunga mawar, pigmen antosianin yang dikandungnya diharapkan dapat memberikan harapan sebagai zat pewarna alami yang menyumbangkan pengganti pewarna berbahaya tersebut. Di negara maju penggunaan zat pewarna alami pada produk makanan sudah digalakkan, produk perwarna alami yang dapat digunakan dalam berbagai aplikasi termasuk minuman, makanan, obat-obatan, suplemen diet, kosmetik, barang kerajinan maupun pakan ternak (US Patent No. 20090246343, Wu et. al, 2008).

Pigmen sebagai senyawa biokatif sangat bermanfaat bagi kesehatan manusia, tidak hanya sebagai zat pewarna alami produk makananminuman namun juga sangat potensial dikembangkan menjadi obat herbal maupun suplemen seperti tablet effervescent, yang akhir-akhir makin marak diminati masyarakat sebagai penyumbang komponen aktif tertentu guna meningkatkan kesehatan. Pigmen antosianin bunga kana dan mawar merah mempunyai sifat sinergis dengan asam sitrat, yang terbukti berfungsi sebagai antioksidan (Lopes, et al., 2010; Garz'on et al., 2009; Yue \& Xu, 2008; Saati dkk., 2008). Apalagi hasil penelitian Konga et al, (2007) menunjukkan bahwa pigmen antosianin mempunyai daya antioksidatif $3-4,5$ kali dari vitamin $\mathrm{E}$, dan dapat membantu menyembuhkan beberapa penyakit (Madhavi, et al., 1996), seperti diabetes melitus (Miyake et. al., 1998). Dengan demikian hasil penelitian ini sangat berharga bagi pengembangan potensi pigmen antosianin bunga mawar merah sebagai zat pewarna alami dan bioaktif (antioksidan) pada beberapa produk agar meningkatkan dayagunanya serta turut mendukung pemberdayaan kekayaan hayati lokal untuk memperbanyak persediaan pangan sehat dan menambah pendapatan masyarakat.

\section{METODE}

Penelitian ini dilaksanakan di Laboratorium Teknologi Hasil Pertanian dan Laboratorium Kimia Universitas Muhammadiyah Malang. Penelitian dilaksanakan pada bulan Juli 2010 sampai dengan April 2011.

Bahan baku yang digunakan sebagai sampel adalah bunga mawar merah segar varietas lokal Batu dari petani mawar Desa Punten Kecamatan Junrejo Batu. Bahan-bahan kimia untuk ekstraksi, isolasi pigmen dan analisa seperti aquades, asam sitrat, kertas saring Whatman no. 41, petroleum eter, etanol, $\mathrm{HCl}, \mathrm{BAA}, \mathrm{BuOH}-\mathrm{HCl}$ sebagai fase gerak (elusi)nya, serta maltodekstrin, sodium bikarbonat dan sukrosa untuk bahan baku pembuatan tablet effervescent. Sedangkan peralatan yang diperlukan antara lain blender, timbangan digital, erlenmeyer, tabung reaksi (pyrex), gelas ukur, sentrifuse, cawan, penyaring vakum VWR scineteific, rotary evaporator vacuum, spketrofotometer IV Vis Shimadzu, $\mathrm{pH}$ meter CG 832 Scholl Gerale, Colour Reader CR10 Konica Minolta (di Laboratorium THP Univ. Muhammadiyah Malang), KLT (Laboratorium Poltek UB Malang).

Peralatan yang digunakan dalam pembuatan tablet effervescent adalah kotak plastik beserta tutup, kain saring, kertas whatman no 41, gelas ukur, sarung tangan karet, timbangan, blender kering, loyang, pengering vakum, ayakan 60 mesh, press hydrolic, cetakan tablet (terdiri: landasan dari baja berlapis chrom stainlees steel (ukuran panjang $=9 \mathrm{~cm}$, lebar $=7 \mathrm{~cm}$ ), cincin/ring dari logam stainlees steel (ukuran diameter dalam $=2,7 \mathrm{~cm}$, tinggi $=2 \mathrm{~cm}$ ), dan as penumbuk dari baja berlapis chrom stainlees steel dengan (ukuran panjang $=10 \mathrm{~cm}$, diameter luar $=$ $2,6 \mathrm{~cm}$ ). Sedangkan peralatan tambahan adalah hardness tester.

Metode penelitian dilakukan dalam 2 tahap, yaitu tahap ekstraki pigmen dan uji kualitas pigmen dari mahkota bunga mawar beberapa pasca potong, sedangkan tahap ke-2 yaitu pengujian efektivitas produk pigmen antosianin bunga mawar merah tersebut pada beberapa produk industri, ada 6 jenis produk industri, yaitu produk sari buah, yoghurt, jelly, minuman berkarbonat, body lotion dan suplemen dalam bentuk tablet effervescent. 
Penelitian dilakukan dalam dua tahapan dengan tiga kali ulangan. Tahap I menguji kualitas ekstrak pigmen bunga mawar pasca potong dalam 3 level yaitu segar $\left(\mathrm{U}_{0}\right), 2$ hari pasca potong bunga $\left(\mathrm{U}_{1}\right)$ dan 4 hari pasca potong bunga $\left(\mathrm{U}_{2}\right)$ yang dilakukan menggunakan rancangan acak lengkap sederhana. Tahap II adalah aplikasi produk pigmen bunga mawar merah pada beberapa produk industri terdiri dari 6 produk (pangan: makanan-minuman, herbal dan kosmetik), menggunakan rancangan sesuai dengan targetnya masing-masing, menggunakan Rancangan Acak Kelompok (RAK) yang disusun secara faktorial, terdiri dari 2 faktor. Faktor yang digunakan dalam penelitian ini adalah prosentase pigmen (A) terdiri dari 3 level $(0,2,4 \%)$ dan jenis produk industri (B), faktor 2 terdiri dari 6 level yaitu sari buah, yoghurt, jelly, minuman berkarbonat (pangan, makmin), tablet effervescent (herbal) dan body lotion (kosmetik).

Tahap pembuatan produk pigmen, diawali dengan melakukan ekstraksi pigmen bunga mawar dengan menimbang mahkota bunga mawar sebanyak 45g, dan dimasukkan ke dalam blender dan ditambahkan pelarut yaitu aquades $95 \mathrm{ml}$, dan asam sitrat 5 gram. Hancuran disimpan dalam lemari pendingin selama 30 menit pada suhu $10^{\circ} \mathrm{C}$ $12^{\mathrm{o}} \mathrm{C}$ supaya pigmen antosianin yang terekstrak lebih maksimal. Kemudian memisahkan filtrat dan ampas mawar dengan penyaringan menggunakan kain saring dan pemerasan. Disaring menggunakan penyaringan vakum (kertas Whatman 41) dan ditambahkan 1-2\% petroleum eter untuk dipisahkan senyawa non antosianin. Bentuk produk pigmen dapat berupa pigmen pekat (konsentrat) dan pigmen bubuk. Pigmen pekat yaitu memproses filtrat pigmen hasil penyaringan (filtrasi) ekstrak pigmen untuk kemudian dipekatkan menggunakan rotary evaporator vacuum pada suhu $40-50^{\circ} \mathrm{C}$. Bubuk pigmen dibuat dengan memproses ekstrak pigmen bunga mawar merah menjadi pigmen bubuk dengan bahan filler yang terdiri dari 3 macam, yaitu dekstrin, gum arab, pati beras dan prosentase penambahannya (ada 3 level: 10,20,30\%), menggunakan rancangan acak kelompok yang disusun secara faktorial. Filtrat hasil ekstrak pigmen dicampur dengan bahan filler (sesuai perlakuan) untuk dimasukkan kedalam oven pada suhu $50^{\circ} \mathrm{C}$ hingga menjadi bubuk pigmen, yang kemudian diayak agar serbuknya berukuran homogen. Pengamatan kualitas pigmen pada tahap penelitian berikutnya meliputi nilai $\mathrm{pH}$, kadar air (AOAC, Sudarmadji, 1998), kelarutan (AOAC, Sudarmadji, 1998), absorbansi (Jenni dkk., 1997), intensitas warna (Fabre et al., 1993) dan rendemen pigmen (Markakis, 1982).

\section{HASIL DAN PEMBAHASAN}

\section{Kandungan Kimia Bahan Baku}

Aroma wangi mahkota bunga mawar ditimbulkan oleh beberapa komponen antara lain gula dan minyak atsiri. Berdasarkan penelitian yang telah dilakukan diketahui bahwa minyak atsiri mawar varietas hibrid dan lokal masing-masing 0,8\%. Hal ini sesuai dengan pendapat Blake (2004), bahwa minyak atsiri yang terkandung pada bunga mawar sekitar 0,06-1,0\% (citronellol, eugenol, asam galat dan linalool. Rerata kadar vitamin $\mathrm{C}$ dan minyak atsiri pada bahan baku dapat dilihat pada Tabel 1 .

Tabel 1. Rerata Kadar Vitamin C dan Minyak Atsiri pada Mahkota Bunga Mawar

\begin{tabular}{lcc}
\hline \multicolumn{1}{c}{ Perlakuan } & $\begin{array}{c}\text { Vit C } \\
(\mathbf{m g})\end{array}$ & $\begin{array}{c}\text { Minyak atsiri } \\
(\boldsymbol{\%})\end{array}$ \\
\hline $\mathrm{U}_{0}$ (mawar segar) & $0,95 \mathrm{c}$ & $0,80 \mathrm{~b}$ \\
$\mathrm{U}_{1}$ (mawar 2 hari pasca potong) & $0,84 \mathrm{~b}$ & $0,78 \mathrm{~b}$ \\
$\mathrm{U}_{2}$ (mawar 4 hari pasca potong) & $0,67 \mathrm{a}$ & $0,44 \mathrm{a}$ \\
\hline
\end{tabular}

Keterangan: Angka rerata dengan huruf yang sama pada kolom yang sama menunjukkan tidak berbeda nyata dengan uji Duncan (DMRT) 5\%.

Selain itu, bunga mawar juga mengandung vitamin. Salah satu vitamin yang terdapat pada bunga mawar varietas hibrid dan lokal adalah vitamin C. Berdasarkan hasil penelitian diketahui bahwa vitamin $\mathrm{C}$ pada bunga mawar hibrid lebih besar $(0,95 \mathrm{mg})$ daripada bunga mawar lokal $(0,67$ mg). Menurut penelitian Saati dkk. (2008), bahwa komponen terbanyak dalam mahkota bunga mawar segar adalah kadar air (83-85 mg), vitamin C (0,5$2 \mathrm{mg}$ ). Kandungan vitamin $\mathrm{C}$ sangat bervariasi tergantung varietas, penyimpanan dan pengolahan semuanya mempengaruhi kandungan vitamin (Tranggono, 1990).

\section{Analisa Bubuk Pigmen Bunga Mawar Kadar Air}

Berdasarkan analisa ragam kadar air diketahui bahwa perlakuan pasca potong bunga mawar tidak berpengaruh terhadap kadar air bubuk pigmen. Rerata kadar air bubuk pigmen pada perlakuan pasca potong bunga mawar dapat dilihat pada Gambar 1 . Perlakuan mawar segar memiliki kadar air relatif lebih tinggi, yaitu sebesar 4,68\%, sedangkan kadar air pada bubuk pigmen dengan 4 hari pasca potong yang relatif lebih rendah yaitu 4,57\% (Gambar 5). Semakin lama bunga disimpan pasca potong, maka kadar air pada bunga tersebut semakin menurun dan bunga menjadi semakin layu. Menurut Tranggono 
(1990), bahwa penurunan kadar air dalam jumlah besar dapat mengakibatkan bahan menjadi layu atau berkerut bahkan mengakibatkan susut berat. Walaupun kehilangan air tersebut menandakan proses pelayuan, namun pelayuan pada mahkota bunga mawar yang akan diekstrak pewarnanya tidaklah merugikan bahkan justru meningkatkan kualitas pigmen antosianin karena menguapkan minyak atsirinya.

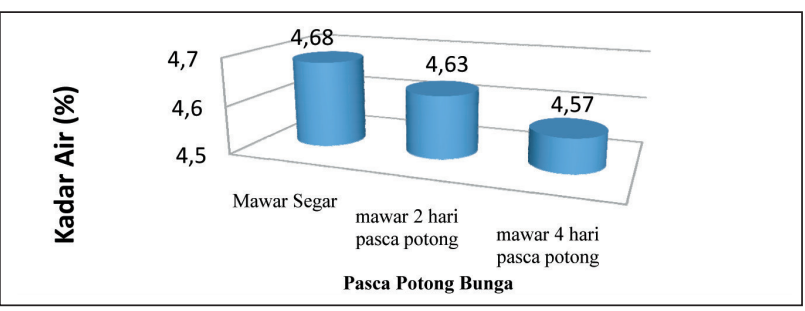

Gambar 1. Diagram Batang Kadar Air Bubuk Pigmen Mawar pada Perlakuan Pasca Potong Bunga Mawar

\section{Total Padatan Terlarut}

Berdasarkan hasil analisa total padatan terlarut (TPT) bubuk pigmen mawar diketahui bahwa perlakuan pasca potong bunga mawar tidak berpengaruh nyata terhadap nilai total padatan terlarut (TPT) bubuk pigmen. Rerata total padatan terlarut pada perlakuan pasca potong bunga mawar dapat dilihat pada Gambar 2.

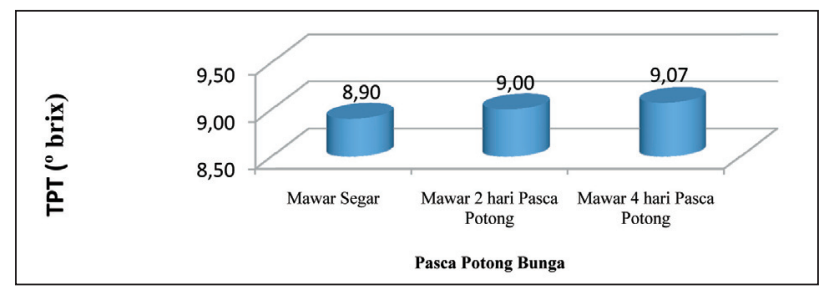

Gambar 2. Diagram Batang Total Padatan Terlarut (TPT) Bubuk Pigmen Mawar pada Perlakuan Pascapotong Bunga Mawar

Berdasarkan analisis data Total Padatan Terlarut (TPT) tertinggi pada bubuk pigmen dihasilkan dari perlakuan mawar 4 hari pasca potong yaitu $9,07^{\circ}$ brix. Nilai TPT tersebut terkait dengan semakin naiknya kandungan gula total pada bubuk pigmen. Sesuai dengan penelitian Saati \& Wachid (2006), bahwa semakin tinggi kadar air maka kadar gula total akan semakin menurun. Nilai TPT pada bubuk pigmen mawar segar yaitu $8,90^{\circ}$ brix dengan kadar air $4,68 \%$. Kadar air yang menurun dan nilai TPT yang meningkat pada perlakuan pasca potong bunga mawar menandakan kualitas pigmen antosianin yang semakin meningkat pula. Hal ini disebabkan karena pigmen antosianin akan terhidrolisis menjadi antosianidin sebagai aglikon dan glikonnya yaitu kandungan gula total. Banyak sedikitnya padatan terlarut ini berhubungan dengan kadar pigmen dalam suatu media pelarut yang tinggi. Daya kelarutan yang tinggi ini berhubungan dengan kepolaran senyawa yang diekstraksi. Adanya kecenderungan kuat bagi senyawa yang polar larut ke dalam pelarut polar dan senyawa non polar larut dalam senyawa non polar (Harborne, 1987), makin lama pasca potong kadar minyak atsiri yang bersifat non-polar makin sedikit sehingga pigmen antosianin yang relatif polar (larut dalam air) makin banyak.

\section{Absorbansi Bubuk Pigmen Mawar}

Tabel 2. Rerata Nilai Absorbansi Bubuk Ekstrak Mawar Merag pada Perlakuan Pasca Potong Bunga Mawar (pada $\lambda=525 \mathrm{~nm}$ )

\begin{tabular}{lc}
\hline \multicolumn{1}{c}{ Perlakuan } & Nilai absorbansi \\
\hline $\mathrm{U}_{0}$ (mawar segar) & $1,09 \mathrm{a}$ \\
$\mathrm{U}_{1}$ (mawar 2 hari pasca potong) & $1,18 \mathrm{~b}$ \\
$\mathrm{U}_{2}$ (mawar 4 hari pasca potong) & $1,22 \mathrm{~b}$ \\
\hline
\end{tabular}

Keterangan: Angka rerata dengan huruf yang sama pada kolom yang sama menunjukkan tidak berbeda nyata dengan uji Duncan (DMRT) $5 \%$.

Berdasarkan analisa ragam nilai absorbansi bubuk pigmen mawar diketahui bahwa perlakuan pasca potong bunga mawar berpengaruh nyata terhadap nilai absorbansi bubuk pigmen. Rerata nilai absorbansi bubuk pigmen pada perlakuan pasca potong bunga mawar dapat dilihat pada Tabel 2 .

Berdasarkan data pada Tabel 2 diketahui bahwa nilai absorbansi tertinggi terdapat pada bubuk pigmen dengan mawar 4 hari pasca potong yaitu 1,22 nm. Pengamatan ini juga ditunjang dengan data kadar air bubuk pigmen mawar 4 hari pasca potong yang relatif lebih rendah $(4,57 \%)$ dibandingkan kadar air bubuk pigmen mawar segar $(4,68 \%)$. Nilai absorbansi bubuk pigmen semakin meningkat dengan semakin lama penyimpanan setelah bunga dipanen. Peningkatan nilai absorbansi terjadi karena pengurangan kadar air pada bubuk sehingga jumlah antosianin semakin meningkat. Hal ini sesuai dengan pendapat Budiarto (1991), bahwa perubahan nilai absorbansi pigmen dipengaruhi oleh jumlah antosianin yang terlarut dan terjadinya perubahan struktur antosianin. Jika warna pigmen masih kemerahan dan tidak sampai berubah menjadi tanpa warna, berarti hanya sebagian antosianin yang rusak atau menjadi berkurang. Macam dan jumlah pigmen antosianin dalam jaringan tanaman tergantung pada spesies, varietas, derajat kematangan, tempat tumbuh dan lain-lain (Tranggono, 1990). 


\section{Intensitas Warna Bubuk Pigmen}

Berdasarkan analisa ragam intensitas warna bubuk pigmen mawar diketahui bahwa perlakuan pasca potong bunga mawar berpengaruh nyata terhadap tingkat kecerahan (L) dan tingkat kemerahan $(\mathrm{a}+)$ bubuk pigmen mawar. Rerata intensitas warna bubuk pigmen pada perlakuan pasca potong bunga mawar dapat dilihat pada Tabel 3.

Tabel 3. Rerata Tingkat Kecerahan (L) dan Kemerahan (a+) Bubuk Ekstrak Mawar Merah pada Perlakuan Pasca Potong Bunga Mawar

\begin{tabular}{lcc}
\hline \multirow{2}{*}{ Perlakuan } & \multicolumn{2}{c}{ Intensitas warna } \\
\cline { 2 - 3 } & \multicolumn{1}{c}{$\mathbf{L}$} & $\mathbf{a +}$ \\
\hline $\mathrm{U}_{0}$ (mawar segar) & $62,23 \mathrm{~b}$ & $26,53 \mathrm{a}$ \\
$\mathrm{U}_{1}$ (mawar 2 hari pasca potong) & $61,43 \mathrm{a}$ & $29,63 \mathrm{~b}$ \\
$\mathrm{U}_{2}$ (mawar 4 hari pasca potong) & $60,73 \mathrm{a}$ & $32,83 \mathrm{c}$ \\
\hline
\end{tabular}

Keterangan: Angka rerata dengan huruf yang sama pada kolom yang sama menunjukkan tidak berbeda nyata dengan uji Duncan (DMRT) 5\%.

Dari hasil pengamatan beberapa kualitas pigmen menunjukkan bahwa ekstrak pigmen dari mahkota bunga mawar 4 hari pasca potong, memiliki kualitas pigmen terbaik, karena mempuyai nilai absorbansi pigmen sebesar 1,22, intensitas warna kemerahan (redness) yaitu 32,83 , total padatan terlarut tertinggi $(9,07)$, dengan didukung oleh kadar air yang paling sedikit (yaitu 4,57\%). Hal ini membuktikan bahwa bunga mawar sortir, yang mungkin telah dianggap tidak segar lagi atau layu, bahkan menjadi sampah dan akan dibuang oleh petani bunga mawar potong, justru masih mengandung pigmen antosianin yang paling banyak. Pemajangan/pasca pemotongan bunga justru menyebabkan minyak atsiri pada mahkota bunga mawar menjadi menguap, dan hal inilah yang membuat kadar antosianin menjadi lebih banyak, karena keduanya mempunyai sifat yang berbeda, minyak atsiri bersifat volatil dan larut dalam pelarut organik seperti alkohol, aseton, eter dan lain-lain (Fennema, 2000), sedangkan pigmen antosianin bersifat larut dalam air (Henry \& Houngton, 1996).

\section{Aplikasi Pigmen pada Produk Industri}

Hasil penelitian Saati dkk. (2009) menunjukkan bahwa pigmen antosianin bunga kana merah dapat stabil dan menyumbangkan warna merah, oranye (merah kekuningan) pada bahan dengan kisaran $\mathrm{pH}$ 1-11, maka dalam penelitian ini aplikasi pigmen dicobakan pada beberapa industri yang berasda pada kisaran range tersebut.

Oleh karenanya sebelum dilakukan aplikasi pigmen antosianin bunga mawar merah maka bahan/sampel dianalisa nilai pHnya terlebih dahulu, kemudian juga dianalisa pHnya setelah ditambahkan pigmen tersebut sebanyak $2-3 \%$, dengan hasil pengamatan seperti pada Tabel 4 .

Tabel 4. Nilai pH beberapa produk industri tang berpotensi untuk disumbang warna alami dari pigmen antosianin bunga mawar merah

\begin{tabular}{lcc}
\hline Jenis produk/Perlakuan & pH awal & $\begin{array}{c}\text { pH setelah } \\
\text { ditambah pigmen }\end{array}$ \\
\hline Sari buah & 3,10 & 3,03 \\
Yoghurt & 4,17 & 4,00 \\
Jelly & 6,50 & 6,51 \\
Minuman berkarbonat & 2,92 & 2,41 \\
Body lotion & 7,20 & 3,77 \\
\hline
\end{tabular}

Hasil pengamatan menunjukkan bahwa beberapa produk industri yang dipilih mempunyai nilai $\mathrm{pH}$ yang masuk dalam kisaran nilai $\mathrm{pH}$ bersifat stabil (Saati dkk., 2009) dan dapat menyumbangkan warna alaminya yaitu kemerahan (redness) dan kekuningan (yellowness), bahkan merah-keunguan, yang dalam produk tersebut tidak begitu tampak. Meskipun menurut Shi, et al. (1992) bahwa pigmen antosianin lebih stabil pada suasana $\mathrm{pH}$ asam yaitu pada kisaran pH 1-5, seperti yang dimiliki oleh produk sari buah $(3,10)$, yoghurt $(4,17)$ dan minuman berkarbonat $(2,92)$. Beberapa produk seperti jelly $(\mathrm{pH} 6,50)$ dan body lotion ( $\mathrm{pH} 7,20)$ tetap dipilih akan dicoba untuk diaplikasikan karena menurut hasil uji karakterisasi Saati, dkk. (2009) bahwa dengan pengenceran pigmen 30 kali atau setara dengan penggunaan pigmen antosianin 3,3\% pada bahan media (larutan buffer) dengan nilai $\mathrm{pH}$ 1-11 masih menampakkan sumbangan warna merah, merah-kekuningan dan pink keunguan pada bahan/media bahan yang ditambahkan. Hasil aplikasi penambahan pigmen antosianin pada beberapa produk industri tersebut dapat dilihat pada Tabel 5 .

Dari Tabel 5 diketahui bahwa hasil pengamatan secara kuantitatif terhadap kelima produk (sari buah, yoghurt, jelly, minuman berkarbonat, body lotion) menunjukkan respon yang positif dengan penambahan pigmen antosianin bunga mawar, berarti pigmen punya potensi besar sebagai zat pewarna alami yang ditandai dengan berkurangnya nilai kecerahan (nilai L) dan bertambahnya nilai kemerahan (redness) sebagai karakter yang menonjol dari pigmen antosianin. Hal ini sesuai dengan pendapat Lewis (1997) bahwa antosianin merupakan pigmen penyebab warna merah, oranye, ungu dan biru, dan mendukung realitas Paten/temuan $\mathrm{Wu}$ et al. (2008), yang menyatakan perwarna alami yang dapat digunakan dalam berbagai aplikasi termasuk minuman, makanan, obat-obatan, suplemen diet, kosmetik seperti body lotion. 
Tabel 5. Nilai intensitas warna beberapa produk industri hasil aplikasi pigmen antiosianin 3,5\%

\begin{tabular}{|c|c|c|c|}
\hline $\begin{array}{c}\text { Jenis Produk/ } \\
\text { Perlakuan }\end{array}$ & Nilai L & $\begin{array}{c}\text { Kemerahan } \\
\text { (redness) }\end{array}$ & $\begin{array}{l}\text { Kekuningan } \\
\text { (yellowness) }\end{array}$ \\
\hline $\begin{array}{l}\text { A0B1:Sari buah tanpa } \\
\text { pigmen }\end{array}$ & 29,50 & 4,40 & 8,80 \\
\hline $\begin{array}{l}\text { A1B1: Sari buah } \\
\text { dengan pigmen }\end{array}$ & 28,47 & 5,13 & 9,00 \\
\hline $2-4 \%$ & 51,03 & 8,03 & 18,77 \\
\hline $\begin{array}{l}\text { A0B2: Yoghurt tanpa } \\
\text { pigmen } \\
\text { A1 B2: Yoghurt dengan }\end{array}$ & 49,47 & 10,47 & 17,87 \\
\hline $\begin{array}{l}\text { pigmen } 2-4 \% \\
\text { A0B3. Jelly tanpa }\end{array}$ & 24,47 & 4,00 & 7,07 \\
\hline $\begin{array}{c}\text { pigmen } \\
\text { A1B3: Jelly dengan }\end{array}$ & 23,30 & 3,30 & 7,43 \\
\hline $\begin{array}{c}\text { pigmen } 2-4 \% \\
\text { A0 B4: Minuman } \\
\text { berkarbonat } \\
\text { tanpa pigmen }\end{array}$ & 34,90 & $-1,30$ & 2,60 \\
\hline $\begin{array}{l}\text { A1B4: Minuman } \\
\text { berkarbonat } \\
\text { dengan pigmen } \\
2-4 \%\end{array}$ & 83,30 & $-1,50$ & 5,90 \\
\hline $\begin{array}{l}\text { A0B5: Body lotion } \\
\text { tanpa pigmen } \\
\text { A1B5: Body lotion } \\
\text { dengan pigmen } \\
2-4 \% \\
\end{array}$ & 82,90 & 3,70 & 6,00 \\
\hline
\end{tabular}

\section{Aplikasi pada Tablet Effervescent Bunga Mawar}

Pigmen sebagai senyawa bioaktif amat bermanfaat jika juga dapat dipergunakan dalam obat-obatan maupun suplemen yang berfungsi meningkatkan kesehatan (Mohre, 1990), karena hasil penelitian yang menunjukkan bahwa pigmen antosianin mempunyai daya antioksidatif 3-4,5 kali dari vitamin $\mathrm{E}$, yang berarti lebih sesuai dengan struktur molekul DNA manusia (Raminez et al., 2001). Oleh karena itu amat bermanfaat selanjutnya pigmen bunga mawar merah tersebut diolah menjadi tablet effervescent, sehingga di samping memberi warna alami pada beberapa produk makananminuman sekaligus juga dapat menyumbangkan antioksidan pada produk tablet yang dihasilkan.
Keterangan Organoleptik Warna dan kenampakan:

$1=$ Sangat tidak merah $\quad 4=$ Merah

$2=$ Tidak merah

$5=$ Sangat merah

$3=$ Agak merah

Keterangan Organoleptik Rasa:

$1=$ Sangat tidak suka $\quad 4=$ Suka

$2=$ Tidak suka

$3=$ Agak suka

5 = Sangat suka

Dalam penelitian ini digunakan bubuk pigmen hasil ekstraksi mahkota bunga mawar merah varietas Lokal batu dan Hibrid belanda, karena kedua varietas tersebut yang banyak dibudidayakan di masyarakat, termasuk oleh petani Desa Punten Kec.Bumiaji, Batu. Untuk penambahan jenis gula, dipilih beberapa jenis gula, seperti gula jagung, gula aren dan gula pasir (sukrosa) yang banyak terdapat sebagai sumberdaya alam Indonesia, agar dapat memanfaatkan potensi kekayaan hayatinya sesuai kondisi lokal/alam masing-masing daerah dengan baik. Pengamatan yang ditampilkan merupakan indikator hasil yang terkait dengan target penggunaan pigmen antosianin dari mahkota bunga mawar merah yaitu warna, kenampakan dan rasa. Berdasarkan analisa ragam diketahui bahwa terjadi interaksi yang sangat nyata antara perlakuan varietas bunga dan jenis gula terhadap kenampakan dan warna tablet effervescent. Rerata skor warna, kenampakan dan rasa tablet effervescent akibat perlakuan varietas bunga mawar dan jenis gula dapat dilihat pada Tabel 6 .

Berdasarkan uji DMRT (5\%) diketahui bahwa perlakuan G2V2 (lokal dan sukrosa 35\%: gula jagung $35 \%$ memiliki warna yang paling disukai panelis yaitu sebesar 3,53 dan yang paling rendah pada perlakuan VIG1 (hibrid: sukrosa 70\%). Penambahan gula sangat berpengaruh pada warna, kambinasi sukrosa dan gula jagung tidak mempengaruhi warna dari pigmen mawar, jika dibandingkan dengan sukrosa dan gula aren.

Tabel 6. Rerata Warna, Kenampakan dan Rasa Tablet Effervescent akibat Interaksi Perlakuan Varietas Bunga Mawar dan Jenis Gula

\begin{tabular}{|c|c|c|c|}
\hline $\begin{array}{l}\text { Perlakuan } \\
\end{array}$ & Warna & Kenampakan & Rasa \\
\hline V1G1: Mawar Hibrid \& Sukrosa 70\% & $2,67 \mathrm{a}$ & $2,2 \mathrm{a}$ & $2,7 \mathrm{ab}$ \\
\hline V1G2 Mawar Hibrid \& Sukrosa: Gula jagung (10\%: 15\%) & $3 \mathrm{a}$ & $3 \mathrm{bc}$ & $3,1 \mathrm{~b}$ \\
\hline V1G3 : Mawar Hibrid \& Gula Aren 70\% & $2,93 \mathrm{a}$ & $3 \mathrm{bc}$ & $2,5 \mathrm{a}$ \\
\hline V1G4: Mawar Hibrid \& Sukrosa: Gula Aren (35\%: 35\%) & $3 \mathrm{a}$ & $3 \mathrm{bc}$ & $2,7 \mathrm{ab}$ \\
\hline V2G1: Mawar Lokal Batu \& Sukrosa 70\% & $2,87 \mathrm{a}$ & $2,7 \mathrm{~b}$ & $2,7 \mathrm{ab}$ \\
\hline V2G2 Mawar Lokal Batu \& Sukrosa: Gula jagung (10\%: 15\%) & $3,53 \mathrm{~b}$ & $3,3 \mathrm{c}$ & $2,9 \mathrm{~b}$ \\
\hline V2G3 Mawar Lokal Batu \& Gula Aren 70\% & $2,8 \mathrm{a}$ & $3 \mathrm{bc}$ & $3 \mathrm{~b}$ \\
\hline V2G5: Mawar Lokal Batu \& Sukrosa: Gula Aren (35\%: 35\%) & $2,93 \mathrm{a}$ & $2,9 \mathrm{bc}$ & $2,9 \mathrm{~b}$ \\
\hline
\end{tabular}

Keterangan: Angka rerata yang diikuti dengan huruf yang sama pada kolom yang sama menunjukantidak berbeda nyata dengan Uji Duncan (DMRT) $5 \%$. 
Skor organoleptik kenampakan larutan tablet effervescent mawar pada perlakuan varietas dan jenis gula tertinggi pada perlakuan V2G2 (lokal dan sukrosa 10\%: Gula jagung 15\%) dengan nilai sebesar 3,3 dan terendah pada perlakuan V1G1 (hibrid: sukrosa 10\%). Hal ini sesuai dengan hasil penelitian Agustin (2009), bahwa penambahan gula gula jagung tidak mempengaruhi warna pigmen, sedangkan penambahan sukrosa dan gula aren warnanya cendrung memudar akibat warna granulanya.

Hasil analisis data menunjukkan bahwa rerata nilai skor organoleptik rasa larutan tablet effervescent mawar pada perlakuan varietas dan jenis gula tertinggi pada perlakuan V1G2 (hibrid dan sukrosa 10\%: gula jagung 15\%) dengan nilai sebesar 3,1 (berarti agak enak, panelis relatif suka), sedangkan terendah pada perlakuan VIG3 (gula aren 10\%) 2,5 (berarti kurang enak). Hal ini disebabkan oleh tingkat kemanisan gula jagung yang lebih tinggi dari pada gula biasa, 2,5 g gula jagung sama dengan $10 \mathrm{~g}$ sukrosa (Anonim, 2010). Jadi dapat disimpulkan bahwa panelis lebih memilih tablet effervescent hasil ekstraksi pigmen bunga mawar merah lokal batu yang ditambah dengan jenis gula sukrosa dan gula jagung (10:15), baik dari aspek skor warna, kenampakan (semua skornya di atas 3,0 berarti mendekati merah) dan skor rasanya, meskipun secara statistik dari aspek rasa ekstrak pigmen bunga mawar merah Hibrid dengan jenis gula yang sama juga lebih disukai panelis (skor nilai mendekati $3,0)$.

\section{SIMPULAN}

Bubuk pigmen antosianin hasil ekstraksi pigmen dari mahkota bunga mawar 4 hari pasca potong, memiliki kualitas pigmen terbaik, karena mempuyai nilai absorbsi pigmen sebesar 1,22, intensitas warna kemerahan (redness) yaitu 32,83, total padatan terlarut tertinggi $(9,07)$, dengan didukung oleh kadar air yang paling sedikit (yaitu $4,57 \%$ ). Pigmen antosianin bunga mawar $2-4 \%$ efektif menyumbangkan warna kemerahan (redness) dan kekuningan (yellowness) pada beberapa produk industri antara lain sari buah, yoghurt, jelly, minuman berkarbonat (pangan, makanan-minuman) dan body lotion (kosmetik) Tablet effervescent hasil ekstraksi pigmen bunga mawar merah lokal batu yang ditambah dengan jenis gula sukrosa dan gula jagung (10:15), baik dari aspek skor warna, kenampakan (semua skornya di atas 3,0 berarti mendekati merah) dan skor rasanya, meskipun secara statistik dari aspek rasa ekstrak pigmen bunga mawar merah Hibrid dengan jenis gula yang sama juga lebih disukai panelis (skor nilai mendekati 3,0). Perlu dikembangkan lebih lanjut tablet effervescent dengan memanfaatkan bunga mawar yang telah mengalami penyimpanan karena semakin lama umur bunga setelah panen, kualitas bubuk pigmen dan tablet effervescent yang dihasilkan tetap baik.

\section{UCAPAN TERIMAKASIH}

Terimakasih kepada Direktorat Penelitian dan Pengabdian kepada Masyarakat DIKTI yang telah membiayai penelitian terkait bunga mawar melalui Penelitian Dosen Muda (Tahun 2005), Penelitian Hibah Bersaing (Tahun 2006-2007 dan 2010) dan telah mendaftarkan Hak Paten: Produk Pewarna Alami Makanan dari Bunga Mawar Merah (Rosa sp) Dan Proses Pembuatannya, No. P0000700579 (Tahun 2007) dan Tablet Effervescent dari Pigmen Bunga Mawar ini, dengan No. P00200900698 pada Desember 2009.

\section{DAFTAR PUSTAKA}

Agustin, I.R. 2009. Studi Pembuatan Tablet Effervescent dengan Menggunakan Ekstrak Bunga Mawar Merah (Rosa damascena Mill) (Kajian Warna Bunga dan Jenis Gula). Skripsi. THP UMM. Malang.

Anonim. 2010. Gula jagung. Diakses pada 5 april 2010 dari http://www. Gula jagung.com.

Blake, S. 2004. Medicinal Plant names, Sample expert, Artikel, http:www. NaturalHealthWizardCom./ MedicinalPlantNames, Sample.html.pdf tanggal akses 12 Agustus 2010.

Budiarto, H. 1991. Stabilitas Antosianin Gurcuna Mangostanan dalam Minuman Berkarbonat. Skripsi Jurusan Teknologi Pangan Gizi. Institut Teknologi Pertanian Bogor.

Fabre, C.E., Santerre A.L., Loret N.O., Baberian R., Parailleux A., Goma, G. and Blanc, P.J., 1993. Production and Food Applications of the Red Pigments of Monascus rubber. J. Food Sci. 58(5): 1099-1110

Fennema, O.R. 2000. Food Chemistry. Marcel Dekker, inc. New York.

Garz'on, G.A. Riedi, K.M. and S.J. Schwartz, 2009. Determination of Anthocyanins, Total Phenolic Content, and Antioxidant Activity in Andes Berry (Rubus glaucus Benth). J. Food Sci. 74(3): 227-232.

Harborne, J.B. 1987. Metode Fetokimia: Penuntun Cara Modern Menganalisa Tumbuhan. Institut Teknologi Bandung. Bandung.

Henry, G.A.F, dan J.O. Houngton. 1996. Natural Food Colorants. Two Edition. Blackie Acidemic and Profetional. London.

Jenie, B.S.L., Helianti dan S. Fardiaz.. 1994. Pemanfaatan Ampas Tahu, Onggok dan Dedak untuk Produksi Pigmen Merah oleh Monascus purpureus. Buletin Teknologi dan Industri Pangan (5): 22-29.

Kompas. 2009. BPOM Tarik 70 Produk Kosmetik Berbahaya. Editor: Rosdianah Dewi. Jakarta, Kompas.com11 Juni 2009. 
Lewis R.J. 1993. Hawley's Condensed Chemical Dictionary. $22^{\text {th }}$ Editions. Van Nostrand Reihold Company. New York.

Lewis, D.H., Bloor, S.J. and Mitchell, K.A, 1997. Flower Colour in Cymbidium, What Makes up The Colour You See?. http://www.crop.cri/nz/meida kit/ Release/971308835.htm

Li, J., 2009, Total anthocyanin content in blue corn cookies as affected by ingredients and oven types. Disertation. Department of Grain Science and Industry College of Agriculture. Kansas University. Manhattan, Kansas. Pp 111.

Lopes, D.J., Dettmann, C.N., and Schieber, A., 2010. Characterization and Quantification of Polyphenols in Amazon Grape (Pourouma cecropiifolia Martius)/ J. Molecules, 15: 8543-8552.

Madhavi, D.L., Desphpande, S.S. and Dalunkhe, DK., 1996. Food Antioxidants, technological, Toxicological and Health Perspectives. IV Series. Marcel Dekker, Inc. New York-Bassel-Hongkong.

Markakis, P., 1982. Anthocyanins as Food Colors. Avademic Press. New York. Pp 263.

Miyake, Y., Yamamoto, K. Tsujihara, N., and Osawa, T., 1998. Protective Effect of Lemon Flavonoids on Oxidative Stress in Diabetic Rats. Lipid, 33: 689695.

Mohre, R. 1990. Effervescent Tablets. Dalam Pharmaceutical Dossage Form: Tablet. Vol 1. $2^{\text {nd }}$ Ed. H.A. Lieberman, L.Lachmand dan J.B. Schwartz (ed). Marcell Dekker Inc. New York.

Nollet, L. M. L. 1996. Hand Book of Food Analysis. Two editions. New York: Marcel Dekker, Inc.

Raminez-Tortosa, C., Yvind M.A., Gardner, PT., Philip C.M., Sharon G.W., Susan J.D., Andrew R.C., and Garry G.D., 2001. Anthocyanin_Rich Extract decreases indices of lipid peroxidation and DNA damage vitamin E-depleted rats. Antioxidants and DNA Damage Group. J.Biol. \& Medicine, 31(9): 1033-1037.
Rukmana, R. 1995. Mawar. Penerbit Kanisius. Yogyakarta.

Saati, E.A., Wachid, M., 2006. Penggunaan Pigmen Antosianin Bunga Mawar Sortiran untuk Pewarna dan Penghambat Kerusakan Lemak pada Pangan Fermentasi. Disampaikan pada Seminar Nasional PATPI 2-3 Agustus 2006, di FTP UGM, Yogyakarta.

Saati, E.A., 2008. Fumction optimalization extract flower of kana as natural colourant and antioxidant by method isolating and characterizing the pigment. Proseding International Reserch Seminar International Reserch Seminar and Exhibition di UMM 7-8 Nopember 2008.

Saati, E.A., 2009. Pendaftaran paten, judul invensi: Tablet Effervescent dari Ekstrak Pigmen Bunga Mawar merah (Rosa sp.) dan proses Pembuatannya. Dibiayai DP2M DIKTI Tahun 2009.

Saati, E.A. 2011. The Anthocyanin Pigment of Red Rose Flower as a Potencial Natural Colorant. Proseding WHR 2011 Nominator Poster Presentations in Halal Science \& Research Excellence, di Kuala Lumpur 6-7 April 2011.

Shi, Z., Lin, M., and Francis, F,J. 1992. Stability of Antocyanin from Tradescania Pallida. J. Food Sci.

Sudarmadji, S., Haryono, B., Suhardi. 1998. Analisa Bahan Makanan dan Pertanian. Liberty dan Pusat antar Universitas Gajah Mada. Yogyakarta.

Tranggono. 1990. Bahan Makanan Tambahan (Food Additive). Pusat antar Universitas Pangan dan Gizi Universitas Gadjah Mada. Yogyakarta.

Wu, Shaowen, C. Ford and G. Horn. 2009. Patent application number: 20090246343: Stable Natural Color Process, Products and Use Thereof.

Yue X. and Z. Xu, 2008. Changes of Anthocyanins, Anthocyanidins, and Antioxidant Activity in Bilberry Extract During Dry Heating. J. Food Chem. 73 (6): 124-135. 